\title{
PROTECTION OF CHILDREN FROM CRIMINAL ACTION IN THE IMPLEMENTATION OF A CHILD-FRIENDLY-CITY
}

\author{
Septiana Prameswari \\ Faculty of Law, Wijaya Kusuma Surabaya University \\ e-mail: tiana.prameswari79@gmail.com
}

\begin{abstract}
Since Indonesia ratified the Convention on the Rights of the Child in the form of the Child Protection Act, the government has now started to pay attention to child issues. Children are in a period of growth, development, and achievement, in which children very easily absorb everything that happens to them, whether good or bad. Sadly, recently, many children have experienced criminal acts that have caused injuries to the children, not only physical injuries but also psychological/mental injuries. The problem of child protection is not only referring to children who are victims of criminal acts that receive legal protection, but also children of witnesses and children of criminal offenders who have the same legal protection needs. Various Problems of violence against children that occur and even polemics in households that consider violence against children is a natural way of educating children has become piecework for the government to protect children from other violent crimes. Currently, the government is trying to build a suitable city structure for children to live in. The regional government's role, all law enforces, and the community is to manifest legal protection for children in a Child-Friendly-City structure.
\end{abstract}

Keywords: Child Protection, Childrens Rights, Child-Friendly-City

\section{INTRODUCTION}

The conversation regarding children's problems will never be finished, the future of the children is the responsibility of all parties. Considering that children are the next generation of Indonesia, the welfare of children needs to be a severe concern for the government.

In recent times, cases of violence against children have been increasing, even the perpetrators of child abuse are still in the neighborhood such as Home/ Family, School, Neighbors, and in public places. However, the most frequent cases of child violence originating from the family environment, economic factors, and psychological factors in the parents/ family are among the main factors in child violence occurrence. There are still many patterns of thought and behavior that make children the object of adults in contrast to the principles of child protection, child protection norms, and children's rights that many still do not know and implement.
Sometimes, parents do not realize that what they do can impact their children, lack of knowledge about the limits in educating children, and even the extent of giving appropriate punishment to children and what children's rights must be fulfilled. Many parents treat their children harshly both verbally and non-verbally, even they argue that what they did is to educate their children. However, without realizing it, this treatment can lead to violence for children. Hence, the child is the victim of a crime in the family.

Indonesia as a country that based on Pancasila and the 1945 Constitution of the Republic of Indonesia (referred now as the 1945 Constitution) guarantees that everyone has the right for not treat discriminated and to avoid violence, Article 28B paragraph (2) stated that "Each child has the right to live, grow up, and develop as well as the right to protection from violence or discrimination. "Furthermore, the issue of legal protection for children on Article 34 
paragraph (1) of the 1945 Constitution explained that" Impoverished persons and abandoned children are to be taken care of by the state," Wagiati Soetedjo and Melani, in their book Hukum Pidana Anak, stated that there is serious attention from the government towards children's rights and protection.

Violence against women and children as victims often occurs in society. Particularly, in married life, ${ }^{1}$ this makes the number of domestic violence cases and violence experienced by children outside the home is difficult to track because this problem is a personal household problem that does not need the intervention of other parties. Sometimes, household problems seen not for public consumption, but if these problems make someone a victim of a criminal act, the problem is no longer the responsibility of the family but also the government's responsibility and the people who know about the incident.

A large number of violence cases that occur, the witnesses and victims who have experienced criminal acts, choose to be silent or do not give their testimony to the authorities due to threats or pressure from the perpetrators of the crime, protection of witnesses exists in all of the criminal justice processes within the judiciary. According to Article 3, protection is based on Respect for human dignity, a sense of security, justice, non-discrimination, and legal certainty. ${ }^{2}$

Foster the child's future is equal to taking care of and saving the future of Indonesia. Consequently, the regulation regarding obligations and responsibilities for the management and protection of children in Indonesia is fundamental. ${ }^{3}$ The State and the Government have the obligation and responsibility to respect and guarantee the human rights of every child despite of ethnicity, religion, race, class, sex, ethnicity, culture and language, legal status, birth order, and physical or mental condition. ${ }^{4}$ The community's obligations and responsibilities towards

\footnotetext{
${ }^{1}$ Titik Suharti. (2006). "Sistem Pertanggungjawaban Pidana Pada Tindak Pidana Kekerasan Dalam Rumah Tangga”. Jurnal Perspektif. XI Number 1, p. 76.

2 Umi Enggarsasi. (2007). "Kedudukan dan Perlindungan Hukum Saksi Sebagai Alat Bukti Yang Sah Dalam Proses Peradilan Pidana di Indonesia". Jurnal Perspektif, XII Number 2, p. 171.

${ }^{3}$ Ahmad Kamil dan Fauzan. (2017). Hukum Perlindungan dan Pengangkatan Anak di Indonesia. Depok: Rajawali Press, p. 71-72.

${ }^{4}$ ibid., p. 72.
}

child protection are carried out through community role activities to implement child protection. Parents have the obligation and responsibility to care for, educate, and protect their children, nurturing children according to their ability to prevent cross-cousinmarriage at the age of children. ${ }^{5}$

The complexity in child problems has come as a particular concern for the Government to fulfill children's rights and the freedom of children from crime. As a result, The Government formed a program named the Child-Friendly City or Kota Layak Anak (KLA). It means that the Regency / City occupied with a child rights-based development system through the integration of commitments. Moreover, Government, community, and business resources are planned comprehensively and sustainably in policies, programs, and activities to ensure the fulfillment of children's rights and protection. (Child).

\section{ISSUES}

Based on the problems described above, a problem formulation are written as follows: The rights of the child that necessary to be fulfilled to create legal protection for the child and the role of the Government in implementing the Child-Friendly City order.

\section{RESEARCH METHOD}

The method that applied in this research is normative. ${ }^{6}$ Written with the Legislative approach and Case Approach. The materials used are the laws and regulations that apply in Indonesia and cases that appear in the community.

\section{DISCUSSION}

The conversation related to children's problems will never finish compliance with the increasing number of cases. Child abuse, child exploitation, bullying, and other cases have resulted in children becoming victims. Before discussing children's rights, it is necessary to know the definition of children according to Law No. 23 of 2002 jo. Law No. 54 of 2014 concerning Child Protection Article 1 point 1 explains that "A child is someone who has not reached 18 (eighteen), including a fetus in the

\footnotetext{
5 ibid.

6 Peter Mahmud Marzuki. (2013). Penelitian Hukum. Jakarta: Kencana, p. 56.
} 
womb." In other words, the Child Protection Law states that everyone who has not 18 years and is still in the womb is referred to as a child or considered immature. In addition, according to Law No. 11 of 2012 Regarding the Juvenile Justice System, what "children" refer to in Article 1 point 2 is "children implicated with the law are children who conflict with the law, children who are victims of criminal acts and children who are the witnesses of criminal acts." Apart from the children of the perpetrators, the children of victims and witnesses are also given the same protection before the law.

\section{a) Violence Against Children and The Impacts}

There are many cases of violence and other crimes that victimize a child. According to data from the Child Protection Agency in the last two years, most types of criminal acts in East Java included sexual violence.

Table I.I Types of Violence in 2018 and $2019^{7}$

\begin{tabular}{clrr}
\hline \multirow{2}{*}{ No } & \multicolumn{1}{c}{ Type of Violence } & \multicolumn{2}{c}{ Year } \\
& & $\mathbf{2 0 1 8}$ & $\mathbf{2 0 1 9}$ \\
\hline 1 & Sexual & 143 & 135 \\
2 & A Child in conflict with Law & 92 & 58 \\
3 & Physical & 46 & 44 \\
4 & Psychological Aggression & 5 & 3 \\
5 & Child Custody & 55 & 50 \\
6 & Economic Exploitation & 11 & 5 \\
7 & Education & 21 & 3 \\
8 & Birth Certificate & - & - \\
9 & Drug, Alcohol, Psychotopic (Napza) & 40 & 18 \\
10 & Murder & 25 & 11 \\
11 & Abandonment & 24 & 23 \\
\hline
\end{tabular}

Regarding the data, we can see almost 100 cases of sexual violence every year. However, the number of violence from 2018 to 2019 has decreased; the rate of violence is still high. Besides that, A child in conflict with Law or Anak Berhadapan Hukum (ABH) is common in cases where the perpetrator is a child, and the victim is still a child. There is also physical violence, such as beatings, domestic violence, torture, and murder. Then, what kind of psychological violence? Bullying, degrading children's dignity, reducing children's self-confidence and others. What happens to children who experience criminal acts? It has a significant impact on the development of the

7 https://suaramuslim.net/lpa-jatim-rumah-dan-sekolahmasih-belum-menjadi-tempat-yang-aman-bagi-anak-anak/ child, in terms of becomes susceptible to depression and expose traumatic symptoms, and ultimately has a high risk of becoming perpetrators of violence. ${ }^{8}$

Alit Kurniasari, in his journal, "The Impact of Violence on Children's Personality," explained that "The personality conditions of children who experience violence from their close community, can lead to various forms of behavior. During that time, they were starting to internalize the treatment that they receive. Furthermore, if the child is subjected to violence simultaneously and physically or sexually, then the child's personal life or psychological condition becomes worse effectuate to physical damage". 9 This matter brings a negative impact on the future when the child victim of a crime does not get their rights for protection. When the child grows up, there is a possibility that the child will commit the same crime when he experienced it first before. The case that occurred in JIS where one of the sodomy perpetrators named Zainal (28) who was a cleaning officer and committed sexual crimes against students at the school, it turned out that Zainal at the age of five had experienced Pedophile crimes by an FBI fugitive named William James Vahey, who was a sociology teacher at JIS from 19922002. The sequence of incidents of sexual crimes explains the existence of repeated crimes against victims due to the failure to fulfill the rights of the victim's child to get protection. The roles of every party are indispensable for the future of children by fulfilling the children's rights and carrying out forcefully in their daily lives. As a result, it can help them recover from the traumatic caused by the crimes they experienced before.

\section{b) The Children's Rights}

The protection of child victims cannot be separated from the rights of children that we required to know, so we will be able to implement them in our daily lives. In order for the protection of children's rights to be manifest, legal regulations are necessary. Article 34 of the 1945 Constitution explains the concern of legal protection for children. It is stated that "Impoverished persons and abandoned children are to be taken care of by the state." The government

8 Alit Kurniasari. (2019). Dampak Kekerasan Pada Kepribadian Anak. Sosio Informa. 5 (1), p. 19.

${ }^{9}$ ibid. 
also put special attention to children's rights and legal protection and address this issue as a background of Law No. 23 of 2002 concerning Child protection, which subsequently changed several articles in the Child Protection Law to Law No. 35 of 2014 about the Amendments to Law No. 23 of 2004.

The government has ratified the Convention on the Rights of The Child (CRC) to establish statutory provisions relating to the achievement of children's rights. Significant efforts related to the ratification of the $\mathrm{CRC}$ are also demonstrated by the stipulation of various laws and regulations relating to children, the establishment of institutions, and action plans in the context of fulfilling children's rights and special child protection. However, many people still have not implemented children's rights. They think that what they do is in terms of how parents educate their children. This is a wrong assumption because there are times when the education delivered by the parents has a limitation. For example, it does not involve physical abuse like beatings, maltreatment, insults, or other acts of violence.

Every child in Indonesia has its rights. The government has regulated the preservation of Children's Rights in Article 4 to Article 18 of the Child Protection Law. The fundamental rights that must be obtained by the children include:

1. Every child is entitled to live, grow, develop, and participate decently in line with dignity of humanity, and acquire protection from violence and discrimination;

2. Every child is entitled for a name as a selfidentity and citizenship status;

3. Every child is entitled to worship in accordance with his/her religion, to think, and to express in line with his/her level of intelligence and age, under parents' guidance;

4. Every child is entitled to know his/her parents, raised, and cared for by his/her own parents. In cases that due to one thing or another the parents cannot guarantee the child's growth and development, or the child is in a neglected state, then the child is entitled to be given care for or adopted as a care given or adopted child in accordance with existing rules and regulation.

5. Every child is entitled to get health services and social security;
6. Every child is entitled to acquire education and teaching in the framework of developing his/her character and level of intelligence in line with his/her interest and talent;

7. Every child is entitled to express, and to be listened to about, his/her opinion, to receive, seek and give information in line with his/her level of intelligence and age for the shake of his/herself development in accordance with appropriateness and decency norms;

8. Every child is entitled to rest and make use of leisure times, socialize with peers, play, recreate and create in line with interest, talent, and level of intelligence for developing him/herself;

9. Every disabled child is entitled to earn rehabilitation, social aids, and up keeping of social welfare;

10. Every child is entitled to have protection and treatment of: discrimination, exploitation, abandonment, cruelty, violence, and molestation, injustice, and other mistreatment;

11. Every child is entitled to acquire protection from: misuse for political activities, being involved in an armed dispute, being involved in social riots, being involved in events that cintain elements of violence, and being involved in a war;

12. Every child is entitled to acquire protection from targets of molestation, torture, or inhuman punishment and also entitled to have freedom;

13. Every child who becomes a victim or actor of sexual assault or who is against the law has the right to be kept confidential and have the right to get legal aids and other aids.

We can conclude from all the children's rights above that we need to pay attention to the fact that children have an essential in the development of the country. The way we treat the children will have an impact on the future of the child and Indonesia. These Children's Rights are manifested from the basic principles of the Convention on the Right of the Child as outlined in Article 2 of Law No. 35 of 2014 concerning Amendments to Law No. 23 of 2002 regarding Child Protection, consist of:

a. Non-discrimination Principle, This meant that children are not differentiated based on religion, race, ethnicity, or between groups. 
b. Child's Best Interest Principle, means by considering the best interest of the children as a priority.

c. Rights to live, survive, and development Principle. This is the most fundamental rights for a child, protected by the state, the government, communities, families, and parents.

d. Principle of respect for a child's opinion, is about the appreciation of the child's rights to participate and express his/her opinion in decision-making process, on matters affecting his/her life.

These four principles are the basis of the Children's Rights, which are the result of the ratification of the Convention on the Rights of The Child and the Legal norms in society. The fulfillment of Children's Rights plays the most crucial role in the family environment because family is the first person we interact with and do activities every day. The rights that must be fulfilled in the family environment include obtaining citizenship status and selfidentity, receiving affection from parents, getting an education, not being exploited, receiving protection from violence and discrimination, and guaranteed all the Children's Rights. The family function is also a function of fostering the environment, which means placing family members in the relationship between families as a community. In the capacity as neighbors, we must protect each other, respect each other, share and remind each other. ${ }^{10}$

The future of a safe, peaceful, and prosperous country will be realized with the implementation of the children's rights. The role of parents, the community, law enforcement officials, and the government is necessary to ensure the children's rights.

\section{c) Child-Friendly City Program}

To accomplish welfare for children, the Central Government, in this case, delegates each region to realize every city/region in Indonesia a feasible, safe, and comfortable city for children. Under the responsibility of the Government (the Regional Government), the child-friendly city program has been implemented in every region. A Child-Friendly

10 Dike Farizan Fadhlillah, Santoso Tri Raharjo, \& Ishartono. (2015). "Pemenuhan Hak Anak Dalam Keluarga Di Lingkungan Prostitusi”. Prosiding Ks: Riset \& Pkm. Vol. 2 No. 1, h. 93
City (KLA) is a Regency/City that has a child rightsbased development system through the integration of commitments and resources from the Government, society and the business world, which is planned comprehensively and sustainably in policies, programs, and activities to ensure the fulfillment of rights and protection child. ${ }^{11}$ The aim of implementing the KLA program, in general, is to fulfill the rights and protect children, while specifically, the KLA aims to build district/city government initiatives that lead to efforts to transform the Convention on the Rights of the Child from a legal framework into a definition, strategy and development interventions, in the form of policies, programs and development activities aimed at the fulfillment of child rights and protection (PHPA), in a district/city. ${ }^{12}$ The parties involved in the development of KLA are the KLA Task Force, which consists of the executive, judiciary, legislative, community, business world, mass media, and children. ${ }^{13}$ There are 5 (five) criterias that given to the region/city who already applied the KLA Program:

1. Child-Friendly City Pratama

2. Child-Friendly City Muda

3. Child-Friendly City Madya

4. Child-Friendly City Nidya

5. Child-Friendly City Utama

The measurement on the indicators of Children's Rights in implementing KLA is necessary to determine which city is included in the KLA criteria. It is consists of 6 (six) institutional indicator and 25 (twenty five) substance indicators grouped into 5 (five) cluster of Children's Rights, that is: ${ }^{14}$

- Civil Rights and Freedoms;

- Family Environment and Alternative Care;

- Basic Health and Welfare;

- Education, Leisure and Cultural Activities;

- Special Protection Measures.

11 The Ministry of Women's Empowerment and Child Protection. (2016). "Kabupaten/Kota Layak Anak: Bahan Advokasi Kebijakan KLA". https://www.kemenpppa.go.id/index. php/page/read/92/1234/k-l-a-kabupaten-kota-layak-anak, h. 1.
12 ibid.
13 ibid. h. 5.
14 ibid., h. 9. 


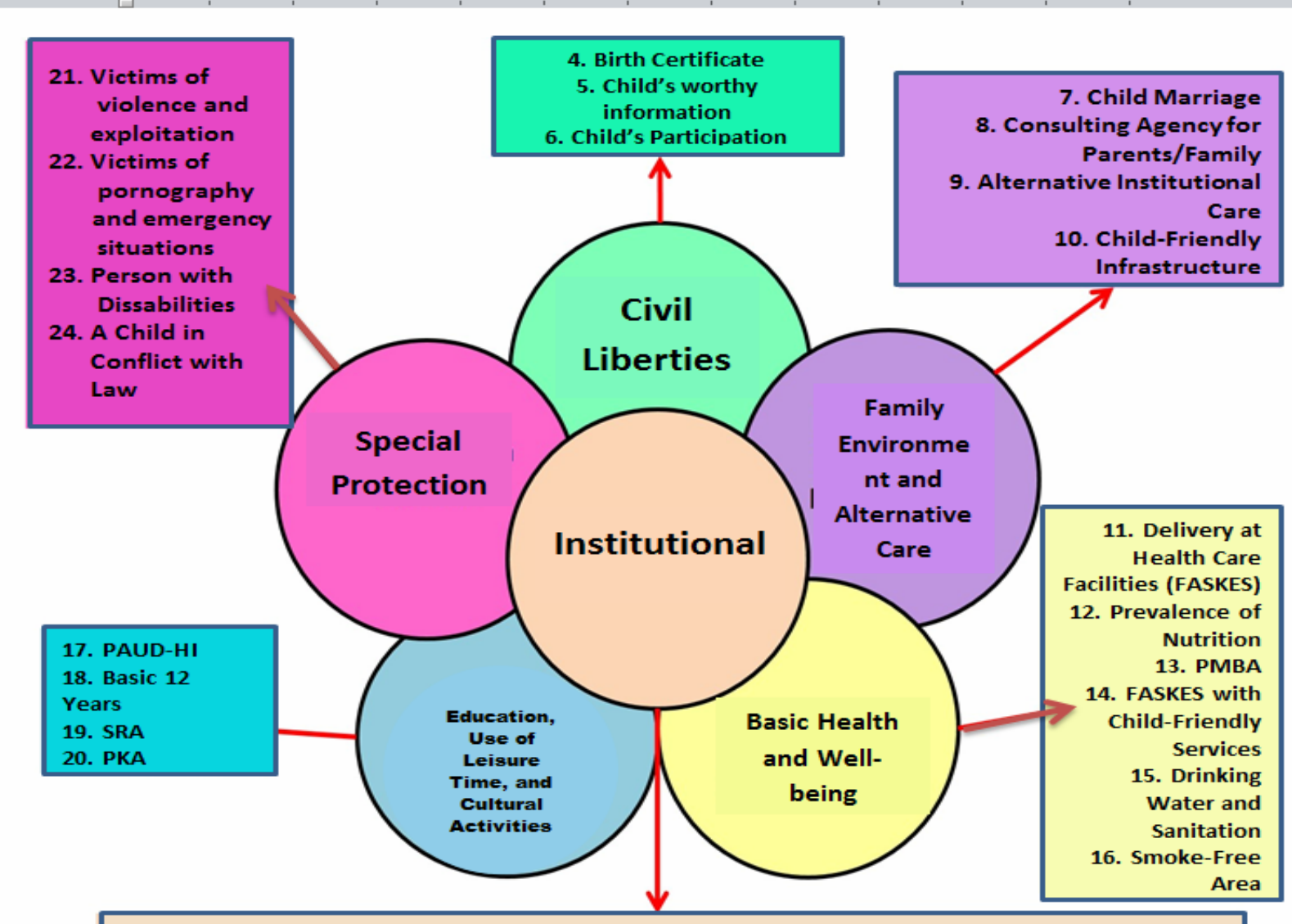

1. “PERDA KLA;2. Institutional KLA; 3. Community, Business \& Media Involvement

The KLA development process refers to the experience of implementing KLA so far, KLA development and expansion of the KLA pilot area can be carried out through various approaches: ${ }^{15}$

a. Bottom-up: It begins from the family, the community movement, extending to RT/RW to Villages/Kelurahan- in the form of "DESA/ KELURAHAN LAYAK ANAK", then extending to the sub-district referred as "KECAMATAN LAYAK ANAK," and ended in the district/city as a "DISTRIK/KOTA LAYAK ANAK."

b. Top-down: It started with the facilitation from the national level, heading to the provinces and ended as districts/cities, called "DISTRIK/ KOTA LAYAK ANAK".

c. Bottom-up and Top-down Combination; While the expansion of the KLA area coverage can be done through the following approaches: Internal and External Replication.

With these approaches, each region can become a reference to create a Child-Friendly City in all parts of

\footnotetext{
15 ibid., h. 7.
}

Indonesia. The KLA program has been implemented by several regions in Indonesia, such as Bojonegoro, Surabaya, Jogjakarta, Solo, Denpasar, Papua, and many more. In 2019, three cities won the title of a Child-Friendly City, including Solo, Denpasar, and Surabaya. The three cities have met all indicators in the Child-Friendly District/City program.

However, if we look further, actually, not all elements of society have not applied the KLA indicator. There are still children who have not been able to get an education. Specialized institutions are needed in each region to help the problems of children faced with the law. It is also necessary to have comprehensive socialization regarding what needs to be done to meet the KLA requirements in society, business, and education so that KLA can be fully implemented in all regions.

\section{CLOSING \\ Conclusion}

Based on the description above, the authors conclude that: Every child has rights that must be 
fulfilled and guaranteed by all levels of society. Children's rights are the responsibility of the state and the government and the responsibility of the family, parents, society, and all law enforcers. Children's rights are based on the Convention on the Rights of the Child, where in principle, children must fulfill the principles of non-discrimination, the best interests of the child, the right to life, survival, and development, and respect for children's opinions. So that the children's rights are formed as stated in Law no. 35 of 2014 concerning Amendments to Law no. 23 of 2002 concerning Protection of children Article 4 to Article 18. Fulfillment of children's rights, the most crucial role is in the family environment, such as obtaining citizenship status and self-identity, receiving affection from parents, getting an education, not being exploited, receiving protection from violence and discrimination, and guaranteed all children's rights. Currently, the Government is creating a ChildFriendly City/KLA program that contains government programs to protect and ensure children's rights are adequately fulfilled. By implementing the 6 (six) KLA indicators in every region in Indonesia, three cities have fulfilled the KLA criteria, which are Solo, Surabaya, and Denpasar. Also, many other cities are still implementing KLA, but there are still many things that need to be done in this KLA program, including extensive socialization to the community, business, and the world of education. Because not a few of the people do not know about this and still cannot implement what should be finished first in a Child-Friendly City scheme.

\section{Recommendation}

The authors argue that further research is necessary regarding this child-friendly city program. There are still many things from the KLA program that have not been fully developed and implemented in various communities. There is a need for individual institutions to help children dealing with the law that are dispersed in various regions. In addition, support from all communities and law enforcement officials also needs to protect and supervise children. The KLA program from the Government can genuinely benefit the fulfillment of children's rights and child protection, and reduce the number of crimes involving children.

\section{REFERENCES}

\section{Laws and Regulations:}

The 1945 Constitution of the Republic of Indonesia.

Law Number 23 of 2002 on Child Protection.

Law Number 35 of 2014 Amending Law Number 23 of 2002 on Child Protection.

Law Number 11 of 2012 on the Child Criminal Justice System.

Surabaya Regional Regulation Number 6 of 2011 on The Implementation of Child Protection.

\section{Books:}

Ahmad Kamil dan Fauzan. (2017). Hukum Perlindungan dan Pengangkatan Anak di Indonesia. Depok: Rajawali Press, p. 71-72.

Peter Mahmud Marzuki. (2013). Penelitian Hukum. Jakarta: Kencana.

\section{Journals:}

Alit Kurniasari. (2019). Dampak Kekerasan Pada Kepribadian Anak. Sosio Informa. 5 (1), p. 19.

Dike Farizan Fadhlillah, Santoso Tri Raharjo, \& Ishartono. (2015). "Pemenuhan Hak Anak Dalam Keluarga Di Lingkungan Prostitusi”. Prosiding Ks: Riset \& Pkm. Vol. 2 No. 1.

Titik Suharti. (2006). "Sistem Pertanggungjawaban Pidana Pada Tindak Pidana Kekerasan Dalam Rumah Tangga”. Jurnal Perspektif, XI Number 1, p. 76.

Umi Enggarsasi. (2007). "Kedudukan dan Perlindungan Hukum Saksi Sebagai Alat Bukti Yang Sah Dalam Proses Peradilan Pidana di Indonesia". Jurnal Perspektif, XII Number 2. p. 171.

\section{Website:}

The Ministry of Women's Empowerment and Child Protection. (2016). "Kabupaten/Kota Layak Anak: Bahan Advokasi Kebijakan KLA". https://www.kemenpppa.go.id/index.php/page/ read/92/1234/k-l-a-kabupaten-kota-layak-anak. 